\title{
Isolation and Selection of Beneficial Microorganism Used for Peanut Growing in Sandy Soil of Binhdinh Province, Vietnam
}

\author{
Pham Van Toan ${ }^{1}$ and Nguyen Thu $\mathrm{Ha}^{2}$ \\ 1. Vietnam Academy of Agricultural Sciences, Hanoi 100000, Vietnam \\ 2. Soil and Fertilizer Research Institute, Hanoi 100000, Vietnam
}

\begin{abstract}
With the aim to apply the beneficial microorganisms to peanut (groundnut (Arachis hypogaea)) growing in sandy soil of Binhdinh province in Vietnam, the paper was conducted to study the isolation, selection of N-fixing, phosphate, potassium solubilizing and slime producing microorganism from sandy soil and peanut root samples, and evaluate the capability of selected isolates to adapt to the sandy soil condition. The isolation and selection of beneficial microbes were based on the biological activity of isolates, which was determined by acetylene reduction assay and nodulation on the peanut for Rhizobium spp., by testing the capability to solubilize $\mathrm{Ca}_{3}\left(\mathrm{PO}_{4}\right)_{2}$ or fenspat in the growth medium for phosphate, potassium solubilizing microbes, and by measurement of the viscosity of Hansen medium for slime producing microorganism. All isolates were evaluated for the effectiveness on the nutrition uptake and growth of peanut by carrying out at the greenhouse and field experiments. To evaluate the adaptation of selected isolates to the sandy soil condition, the experiments were carried out in the laboratory to determine the microbial density in suitable medium, containing different $\mathrm{NaCl}$ concentrations or with different $\mathrm{pH}$ or at different temperatures. The results showed that rhizobial strain RA18 had an N-fixing activity value of 3,458 $\pm 10.95 \mathrm{nmol} \mathrm{C}_{2} \mathrm{H}_{2} /$ plant and can supply $30 \%$ of $\mathrm{N}$ required for peanut. The bacterial strain P1107 is able to solubilize phosphate and can increase phosphorus uptake by $30 \%$ in peanut. Further, inoculation of peanut with the bacterial strain S3.1 can save 30\% required mineral potassium, and the Lipomyces strain PT5.1 can produce the slime, which can provide the sandy soil to keep moisture for $15 \mathrm{~d}$ longer than the control without the inoculation. All selected isolates are able to grow at temperatures from $20^{\circ} \mathrm{C}$ to $35{ }^{\circ} \mathrm{C}$, $\mathrm{pH}$ from 4.5 to 6.0 and the salinity of $0.2 \%$ - $0.6 \%$ o $\mathrm{NaCl}$, and can well adapt to the sandy soil conditions.
\end{abstract}

Key words: Sandy soil, peanut, N-fixing Rhizobium, phosphate and potassium solubilizing bacteria, slime yeast Lipomyces.

\section{Introduction}

Biofertilizers are products containing cell of different types of beneficial microorganisms, such as N-fixing, phosphate solubilizing or cellulolytic microorganisms used for application of seed, soil or composting areas to increase the numbers of beneficial microorganisms and extend the availability of nutrients in a form which can be assimilated by plant. Common biofertilizers are $\mathrm{N}$ fixers, $\mathrm{K}$ solubilizer and $\mathrm{P}$ solubilizer or with the combination of them. Most of the bacteria contained in biofertilizer

Corresponding author: Pham Van Toan, associate professor, research field: biotechnology. have a close relationship with plant roots.

Symbiotic N-fixing and phosphate solubilizing microorganisms play an important role in supplementing $\mathrm{N}$ and $\mathrm{P}$, respectively, to the plant [1]. $\mathrm{N}$ inputs through biological $\mathrm{N}$ fixation support sustainable and environment friendly agricultural production. The value of $\mathrm{N}$-fixing legumes in improving yield of legumes and other crops can be achieved by the application of biofertilizers [2]. Phosphate solubilizing bacteria have the capacity to convert inorganic unavailable $\mathrm{P}$ form to soluble forms $\left(\mathrm{HPO}_{4}\right)_{2}{ }^{-}$and $\mathrm{H}_{2} \mathrm{PO}_{4}$ through the process of organic acid production, chelating and ion exchange reactions, and make them available to plants. Phosphate 
solubilizing bacteria can also mobilize insoluble $\mathrm{P}$ from fertilizers and soils to soluble $\mathrm{P}[3,4]$. In addition, phosphate solubilizing microorganisms can improve the plant growth by enhancing the availability of other trace element, such as iron (Fe), zinc (Zn), etc. [5], and synthesize enzymes that can modulate plant hormone level, may limit the available iron via siderophore production and can also kill the pathogen with antibiotic [6].

The inoculation with bacterial mixtures provided more nutrition for the plants and the improvement in root uptake of $\mathrm{N}$ and $\mathrm{P}$. Co-inoculation of some phosphate solubilizing bacteria, like Pseudomonas and Bacillus, with effective Rhizobium spp., is shown to stimulate chickpea growth, nodulation, $\mathrm{N}$ fixation and have significant effects on nutrient uptake of chickpea [7]. From results of field experiments and field demonstration, Toan [8] concluded that $\mathrm{N}$-fixing inoculants on peanut can reduce $\mathrm{N}$ application by 30-60 kg N/ha/year, and increase the crops yield by $5 \%$ to $25 \%$. On peanuts, phosphate solubilizing inoculants and rock phosphate can replace 30\%-50\% mineral P fertilizer without significant change of crops yield, and mixing of symbiotic $\mathrm{N}$-fixing and phosphate solubilizing microorganisms have the same yield, like reducing $20 \%$ of basal mineral $\mathrm{N}$ and $\mathrm{P}$ doses.

Peanut, also known as groundnut (Arachis hypogaea) is a crop of global importance and widely cultivated in tropical and subtropical regions. World annual production is about 46 million tons per year [9]. Vietnam has peanut growing area of 208,000 ha in all ecological zones. In last 10 years, the peanut yield in Vietnam increased continuously and reached 2.18 tonnes/ha in 2014, but low compared to other countries, like Israel, America, China and Brasilia. Sandy soil is widely used for peanut production in Vietnam, but it has some constraints for agricultural production, like acid, low inorganic matter, poor in plant nutrients and suffering from serious wind and water soil erosion [10]. New management to improve the sandy soils fertility already has been reported by Ha et al. [11], but not easy to realize. Practical peanut production in Vietnam needs new solution for sandy soils management.

The purpose of this paper was to isolate, select and evaluate the capability of beneficial microbes used as biofertilizer for peanut growing in sandy soil of Binhdinh province.

\section{Materials and Methods}

Soil and root of peanut were collected following the Vietnam standard [12]. The analyse of the chemical properties was done according to the methods described in Vietnam standard [13-18]. The Rhizobium spp. are isolated and evaluated for nodulation on the peanut by methods described by Berk et al. [19]. The N-fixing activity of selected rhizobial strains was determined by acetylene reduction assay according the method described in Vietnam standard [20].

Phosphate and potassium solubilizing bacteria were isolated from soil samples by serial dilution plate count method using Pikovskaya medium for phosphate solubilizer and Aleksandrov medium for potassium solubilizing microbes, respectively. The phosphate and potassium solubilizing activities were determined through the available $\mathrm{P}$ and $\mathrm{K}$ in the supernatant of growth medium, using the flame photometric method described by Sugumaran and Janarthanam [21] for potassium solubilizer and according to the method described by Gaur [22] for phosphate solubilizer, respectively.

To isolate the slime yeast (Lipomyces spp.), soil samples were ground, mixed with water to make a soil ball, placed on agar disk containing Hasen medium and incubated at $28-30{ }^{\circ} \mathrm{C}$ for three weeks. The slime apperance around the soil ball was observed to isolate and purify the slime producing microorganisms. The activity of slime producing microorganisms was determined by the method described by Tam [23] as the viscosity of Hansen medium inoculated with 
isolated Lipomyces spp. after 3 d cultivated on shaker at temperature of $28-30{ }^{\circ} \mathrm{C}$. The viscosity was meassured using the Elcometer 2300 and calculated by software Viscosity Master ${ }^{\mathrm{TM}}$ as $\mathrm{N} \cdot \mathrm{s} / \mathrm{m}^{2}$.

To evaluate the effect of isolates on nutrient uptake by peanut, the pot experiments were conducted using the seed inoculation methods with the microbial density of $10^{6} \mathrm{CFU} / \mathrm{seed}$. Mineral N, P, K were applied with a dose of $0.64 \mathrm{~g}$ urea, $2.5 \mathrm{~g}$ super $\mathrm{P}$ and $0.5 \mathrm{~g} \mathrm{KCl}$ per $10 \mathrm{~kg}$ pot for the control. As experimental treatments with inoculation, the amount of mineral fertilizers was reduced $10 \%, 20 \%$ and $30 \%$ of required $\mathrm{N}$ for $\mathrm{N}$ fixer, $10 \%, 20 \%$ and $30 \%$ of required $\mathrm{P}$ for phosphate solubilizer or $10 \%, 20 \%$ and $30 \%$ of required $\mathrm{K}$ for potassium solubilizer, respectively.

For study on the moisture keeping of sandy soil inoculated with slime Lipomyces spp., pot experiment was also conducted. Sandy soil was inoculated with Lipomyces spp. at density of $10^{6} \mathrm{CFU} / \mathrm{g}$ soil and has the initial moisture of $40 \%$. The moisture of soil was meassured using moisture probe meter in the time of 15, 30, 45 and $60 \mathrm{~d}$ after inoculation according to the Vietnam standard TCVN 4048:2011 [24].

The experiments were carried out in the laboratory to study the capability of isolates to adapt the sandy soil condition. Each isolate was grown in a suitable medium containing $\mathrm{NaCl}$ concentration of $0.2 \%$ - $0.6 \%$, with $\mathrm{pH}$ from 4.5 to 6.0 , at different temperatures ranging from $20{ }^{\circ} \mathrm{C}$ to $35{ }^{\circ} \mathrm{C}$. The microbial density of each isolate was determined by plate count method at the time of $48 \mathrm{~h}$ after cultivation.

All experiments were repeated three times and data analysis was carried out using the IRRISTAT and Excel program.

\section{Results and Discussion}

\subsection{Chemical and Biological Properties of Sandy Soil}

The analysis of chemical and biological properties of sandy soil in the research area in Table 1 showed that soil had low moisture, organic matter and $\mathrm{pH}$, salinity of $0.17 \%$ o- $0.26 \% \mathrm{NaCl}$, very low in total and available nutrients and low population of beneficial microbes. There are the main constraints for crops production in this area like other sandy soil in costal area in Vietnam reported by Vinh [10] and Ha et al. [11].

\subsection{Isolation and Selection of Beneficial Microbial Strains}

\subsubsection{N-Fixing Activity}

From nodules of peanut grown in sandy soil, six rhizobial strains were isolated and tested for the $\mathrm{N}$-fixing

Table 1 Chemical and biological properties of sandy soil in Phucat, Binhdinh.

\begin{tabular}{lll}
\hline Soil properties & Cattrinh commune & Cathiep commune \\
\hline Moisture (\%) & $4.60 \pm 0.400$ & $4.40 \pm 0.320$ \\
$\mathrm{pH}(\mathrm{KCl})$ & $4.80 \pm 0.180$ & $4.60 \pm 0.130$ \\
Soil salinity (\%) & $0.26 \pm 0.050$ & $0.17 \pm 0.040$ \\
Organic matter (\%) & $0.18 \pm 0.020$ & $0.18 \pm 0.014$ \\
Total $\mathrm{N}(\% \mathrm{~N})$ & $0.03 \pm 0.007$ & $0.04 \pm 0.006$ \\
Total P $\left(\% \mathrm{P}_{2} \mathrm{O}_{5}\right)$ & $0.01 \pm 0.005$ & $0.02 \pm 0.004$ \\
Total K $\left(\% \mathrm{~K}_{2} \mathrm{O}\right)$ & $0.01 \pm 0.003$ & $0.02 \pm 0.005$ \\
Available $\mathrm{P}\left(\mathrm{mg} \mathrm{P}_{2} \mathrm{O}_{5} / 100\right.$ g soil) & $6.31 \pm 0.152$ & $4.20 \pm 0.158$ \\
Available K (mg K $\mathrm{K}_{2} / 100$ g soil) & $1.34 \pm 0.062$ & $2.14 \pm 0.367$ \\
\hline Microbial density $(\mathrm{CFU} / \mathrm{g})$ & & \\
\hline $\mathrm{N}$ fixer & $(2.08 \pm 0.13) \times 10^{4}$ & $(2.20 \pm 0.19) \times 10^{4}$ \\
P solubilizer & $(1.10 \pm 0.10) \times 10^{4}$ & $(1.90 \pm 0.40) \times 10^{4}$ \\
K solubilizer & $(2.52 \pm 0.30) \times 10^{4}$ & $(1.45 \pm 0.41) \times 10^{4}$ \\
Slime producer & $(5.80 \pm 0.29) \times 10^{3}$ & $(1.56 \pm 0.25) \times 10^{4}$ \\
\hline
\end{tabular}


Table 2 The $\mathrm{N}$-fixing capability of some rhizobial strains isolated from nodules of peanut growed in sandy soil in Phucat, Binhdinh.

\begin{tabular}{lll}
\hline Rhizobial strains & Nodules number per plant & N-fixing activity (nmol $\left.\mathrm{C}_{2} \mathrm{H}_{2} / \mathrm{plant}\right)$ \\
\hline RA1 & $58.2 \pm 2.86$ & $2,355 \pm 8.94$ \\
RA4 & $55.5 \pm 2.77$ & $1,514 \pm 9.06$ \\
RA16 & $60.2 \pm 2.28$ & $3,100 \pm 14.82$ \\
RA18 & $65.8 \pm 2.59$ & $3,458 \pm 10.95$ \\
RA22 & $54.6 \pm 3.58$ & $1,600 \pm 8.34$ \\
RA25 & $54.0 \pm 2.77$ & $1,250 \pm 9.35$ \\
\hline
\end{tabular}

Table 3 Effect of rhizobial strain RA18 on yield of peanut.

\begin{tabular}{lllll}
\hline Treatments & $\begin{array}{l}\text { N content of green } \\
\text { biomass (g/pot) }\end{array}$ & $\begin{array}{l}\text { Nodule number } \\
\text { (nodule/plant) }\end{array}$ & $\begin{array}{l}\text { Dry green biomass } \\
\text { (g/pot) }\end{array}$ & Pod yield (g/pot) \\
\hline $100 \%$ NPK & 1.55 & 186.00 & 81.80 & 25.50 \\
$100 \%$ NPK + RA18 & 2.02 & 220.00 & 89.80 & 28.56 \\
$90 \%$ N + 100\% PK+ RA18 & 1.98 & 216.00 & 88.40 & 27.82 \\
$80 \%$ N + 100\% PK + RA18 & 1.80 & 207.00 & 86.80 & 27.61 \\
$70 \%$ N + 100\% PK + RA18 & 1.59 & 200.60 & 83.50 & 26.38 \\
\hline CV (\%) & 5.90 & 3.20 & 2.80 & 3.00 \\
LSD & 0.05 & 12.50 & 4.50 & 1.50 \\
\hline
\end{tabular}

Table 4 The capability of isolates to solubilizing the $\mathrm{Ca}_{3}\left(\mathrm{PO}_{4}\right)_{2}$.

\begin{tabular}{llc}
\hline Microbial strains & $\begin{array}{l}\text { Diameter of } \mathrm{Ca}_{3}\left(\mathrm{PO}_{4}\right)_{2} \text { solubilizing zone } \\
(\mathrm{mm})\end{array}$ & $\begin{array}{l}\text { Concentration of available P in the medium } \\
\left(\mathrm{mg} \mathrm{P}_{2} \mathrm{O}_{5} / 100 \mathrm{~mL}\right)\end{array}$ \\
\hline P55 & $12.0 \pm 0.35$ & $15.2 \pm 0.45$ \\
P100 & $16.2 \pm 0.45$ & $18.5 \pm 0.50$ \\
P114 & $14.9 \pm 0.22$ & $16.6 \pm 0.47$ \\
P1107 & $18.0 \pm 0.35$ & $21.2 \pm 0.27$ \\
P1108 & $15.9 \pm 0.42$ & $16.8 \pm 0.57$ \\
\hline
\end{tabular}

activity. The results in Table 2 showed that the rhizobial strain RA18 can nodulate more $(65.8 \pm 2.59$ nodules/per plant) and had higher ARA activity (3,458 $\pm 10.95 \mathrm{nmol} \mathrm{C}_{2} \mathrm{H}_{2}$ /plant) than other isolates, so can be used for further study. Similar results were obtained by Toan [8] and Hiep [25], when they evaluated the $\mathrm{N}$-fixing activity of rhizobial isolated from red and black soils in Vietnam.

Rhizobial strain RA18 was tested for N supplement to peanut. The results in Table 3 indicated that inoculation of peanut with rhizobial strain RA18 can save more than $30 \%$ of required mineral N. Sandy soil is general low in nutrients and organic matter $[10,11]$, which may have negative effect on the symbiotic relationship between Rhizobium and peanut root. This is the reason for the lower N-supplement in the study compared to the results obtained by Toan [8] and Hiep [25], who reported that the rhizobial inoculation can save $40 \%-60 \%$ of required mineral $\mathrm{N}$.

\subsubsection{Phosphate Solubilizing Activity}

From sandy soil samples, five phosphate solubilizing bacterial strains are isolated and evaluated for the phosphate solubilizing activity. The data in Table 4 showed that all isolates were able to solubilize the $\mathrm{Ca}_{3}\left(\mathrm{PO}_{4}\right)_{2}$. The results are in line with those obtained by Hiep [25]. The bacterial strain P1107 has higher potential to solubilize the $\mathrm{Ca}_{3}\left(\mathrm{PO}_{4}\right)_{2}$, i.e., solubilize more larger size $(18.0 \pm 0.35)$ of $\mathrm{Ca}_{3}\left(\mathrm{PO}_{4}\right)_{2}$, compared to other isolates, and thus it will be used for further experiment.

Bacterial strain P1107 was tested for improving the $\mathrm{P}$ uptake of peanut. The result in Table 5 showed that by using bacterial strain P1107 inoculation and reduction of $30 \%$ required mineral $\mathrm{P}$, peanut green biomas and pod yield had no significant difference with the control. The analysis of $\mathrm{P}_{2} \mathrm{O}_{5}$ content of green 
Table 5 Effect of bacterial strain P1107 on yield of peanut.

\begin{tabular}{llll}
\hline Treatments & $\mathrm{P}_{2} \mathrm{O}_{5}$ content of green biomas (g/pot) & Dry green biomas (g/pot) & Pod yield (g/pot) \\
\hline $100 \%$ NPK (control) & 0.18 & 81.80 & 25.50 \\
$100 \%$ NPK + P1107 & 0.20 & 89.80 & 27.56 \\
$90 \%$ P + 100\% NK + P1107 & 0.20 & 85.90 & 26.77 \\
$80 \%$ P + 100\% NK + P1107 & 0.18 & 82.50 & 26.62 \\
$70 \%$ P + 100\% NK + P1107 & 0.17 & 78.30 & 25.70 \\
\hline CV (\%) & 3.70 & 2.80 & 2.20 \\
LSD & 0.01 & 3.35 & 1.09 \\
\hline
\end{tabular}

Table 6 The capability of isolates to solubilizing the fenspat.

\begin{tabular}{lll}
\hline Microbial strains & $\begin{array}{l}\text { Diameter of fenspat solubilizing zone } \\
(\mathrm{mm})\end{array}$ & $\begin{array}{l}\text { Concentration of available K in the medium } \\
\left(\mathrm{mg} \mathrm{K}_{2} \mathrm{O} / 1,000 \mathrm{~mL}\right)\end{array}$ \\
\hline S1.1 & $8.20 \pm 0.27$ & $18.40 \pm 0.31$ \\
S3.1 & $12.00 \pm 0.35$ & $19.20 \pm 0.21$ \\
S3.3 & $7.80 \pm 0.45$ & $16.00 \pm 0.27$ \\
S8 & $6.40 \pm 0.42$ & $12.50 \pm 0.35$ \\
S10 & $8.00 \pm 0.35$ & $16.40 \pm 0.44$ \\
S11.2 & $7.60 \pm 0.31$ & $15.60 \pm 0.31$ \\
\hline
\end{tabular}

Table 7 Effect of bacterial strain S3.1 on yield of peanut.

\begin{tabular}{llll}
\hline Treatments & $\mathrm{K}_{2} \mathrm{O}$ content of green biomas (g/pot) & Dry green biomas (g/pot) & Pod yield (g/pot) \\
\hline $100 \%$ NPK (Contro) & 1.04 & 81.80 & 25.50 \\
$100 \%$ NPK+ S3.1 & 1.18 & 87.20 & 28.42 \\
$90 \% \mathrm{~K}+100 \% \mathrm{NP}+\mathrm{S} 3.1$ & 1.14 & 84.40 & 27.63 \\
$80 \% \mathrm{~K}+100 \% \mathrm{NP}+\mathrm{S} 3.1$ & 1.12 & 83.80 & 26.83 \\
$70 \% \mathrm{~K}+100 \% \mathrm{NP}+\mathrm{S} 3.1$ & 1.04 & 81.00 & 25.15 \\
\hline $\mathrm{CV}(\%)$ & 3.70 & 2.80 & 2.20 \\
$\mathrm{LSD}$ & 0.08 & 1.78 & 1.20 \\
\hline
\end{tabular}

biomas showed the same result. Similar results were obtained by Hiep [25]. The data in this study indicated that bacterial strain P1107 was able to increase P uptake by $30 \%$ in peanut.

\subsubsection{Potassium Solubilizing Activity}

From sandy soil samples, six potassium solubilizing bacterial strains were isolated and evaluated for the potassium solubilizing activity. The data presented in Table 6 showed that all isolates were able to solubilize the fenspat and make fenspat to provide available $\mathrm{K}$ for plant. While the bacterial strain S3.1 has the highest potential, i.e., can solubilize the largest size (12.0 $\pm 0.35 \mathrm{~mm})$ of fenspat, and can be used for the further study. The potassium solubilizing activity of microbes depended on the mineral resources and also on the $\mathrm{pH}$ and aerobic condition. Badr [26] found that the release of $\mathrm{K}$ in order was illite $>$ fenspat $>$ muscovite.

Bacterial strain S3.1 was tested for improving the $\mathrm{K}$ uptake of peanut. The results in Table 7 showed that peanut had the same green biomas, pod yield and green biomas $\mathrm{K}_{2} \mathrm{O}$ content by inoculation with bacterial strain S3.1 and reduction of 30\% required mineral $\mathrm{K}$ compared to the control. The data in this study indicated that bacterial strain S3.1 was capable to support the peanut with an uptake of $30 \% \mathrm{~K}$ more. Similar results were obtained by Sheng [27], who by conducting the pot experiment with K-deficiency soil on cotton and rape seed, reported the $\mathrm{K}_{2} \mathrm{O}$ content of green biomas $30 \%$ higher than the control without inoculation. 
Table 8 The capability of Lipomyces isolates to produce the polysaccharid.

\begin{tabular}{lll}
\hline Lipomyces strains & Viscosity $\left(10^{-3} \mathrm{~N} \cdot \mathrm{s} / \mathrm{m}^{2}\right)$ & Dry weight of polysaccharid in growth medium $(\mathrm{g} / \mathrm{L})$ \\
\hline PT2 & $26.50 \pm 0.79$ & $34.50 \pm 0.55$ \\
PT1 & $26.40 \pm 0.84$ & $32.00 \pm 0.61$ \\
PT5.1 & $37.60 \pm 0.42$ & $36.00 \pm 0.62$ \\
PT12 & $30.80 \pm 0.57$ & $31.80 \pm 0.35$ \\
PT15 & $25.60 \pm 0.55$ & $30.80 \pm 1.15$ \\
PT39 & $10.40 \pm 0.42$ & $16.20 \pm 0.57$ \\
\hline
\end{tabular}

Table 9 Effect of Lipomyces strain PT5.1 on the improvement of sandy soil moisture.

\begin{tabular}{lll}
\hline \multirow{2}{*}{ Time after inoculation (day) } & \multicolumn{2}{c}{ Soil moisture (\%) } \\
\cline { 2 - 3 } & Control without inoculation & Experiment \\
\hline 0 & 40.00 & 40.00 \\
15 & 24.20 & 35.40 \\
30 & 22.60 & 28.40 \\
45 & 18.30 & 22.50 \\
60 & 13.00 & 16.80 \\
\hline $\mathrm{CV}(\%)$ & 2.30 & 2.60 \\
$\mathrm{LSD}_{0.05}$ & 0.97 & 1.00 \\
\hline
\end{tabular}

\subsubsection{Moisture Keeping Ability}

Purposed to improve the moisture keeping for sandy soil, six slime Lipomyces isolated were tested for slime production. From the data in Table 8, it can be seen that all isolates were able to produce slime, and the best strain is PT5.1, which can produce $36 \mathrm{~g}$ dry polysaccharid in $1 \mathrm{~L}$ growth medium.

Lipomyces strain PT5.1 was inoculated to soil with a moisture of $40 \%$ at the beginning of experiment. The results in Table 9 showed that Lipomyces strain PT5.1 can help the soil to keep its moisture content $15 \mathrm{~d}$ longer than the control without the Lipomyces strain PT5.1 inoculation. Similar results were obtained by Tam [23] on research of the capability of Lipomyces to improve the soil moisture in Me Linh, Vinh Phuc province.

\subsection{Evaluation of the Adaptation Capability of Isolates to Sandy Soil Condition}

Soil physico-chemical properties can affect the growth and metabolism of microorganisms, thus influencing soil microbial activities. Salinity may restrain microbial activity and increase in soil salinity, leading to decreased soil microbial biomass and soil enzyme activities [28, 29]. Purposed to produce inoculant for peanut growing in sandy soil, there was a need to evaluate the adaption of selected isolates

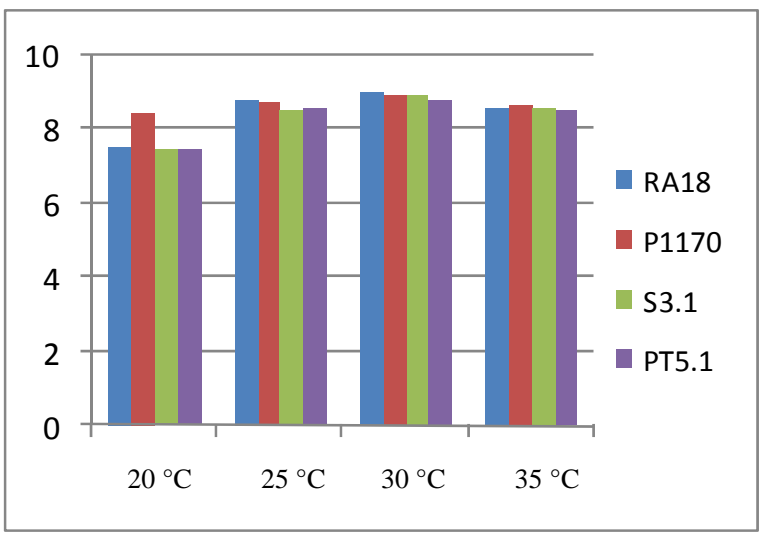

Fig. 1 Density of isolates in the growth medium at different temperature $\left(\log _{10}\right)$.

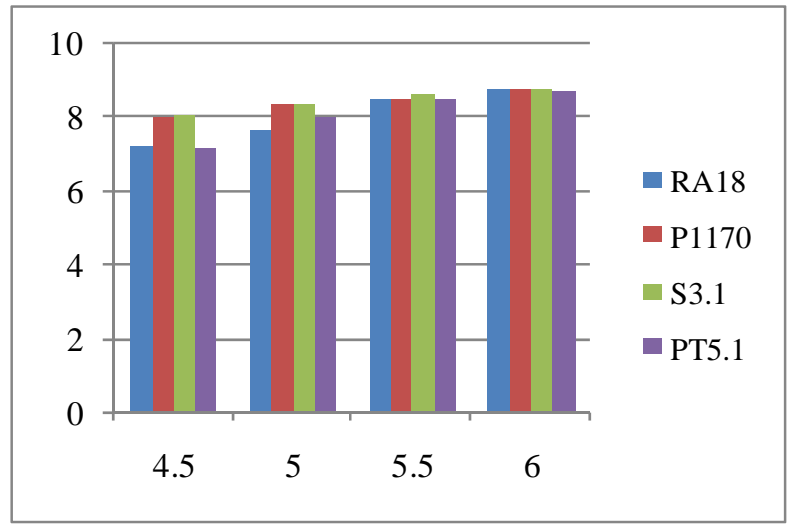

Fig. 2 Density of isolates in the growth medium with different $\mathrm{pH}\left(\log _{10}\right)$. 


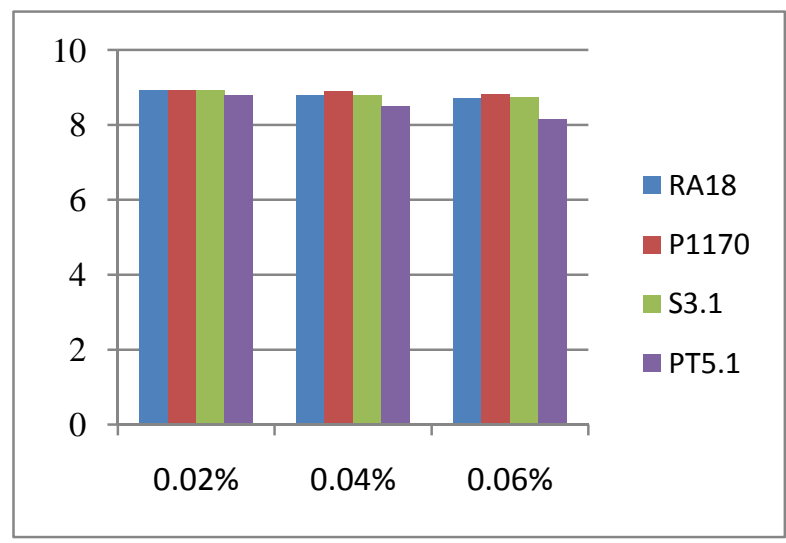

Fig. 3 Density of isolates in the growth medium containing different $\mathrm{NaCl}$ concentration $\left(\log _{10}\right)$.

(RA18, P1107, S3.1 and PT5.1) to the sandy soil condition. From Figs. 1-3, it can be seen that all selected microbial strains were able to grow at temperature from $20^{\circ} \mathrm{C}$ to $35{ }^{\circ} \mathrm{C}$, $\mathrm{pH}$ from 4.5 to 6.0 and salinity of $0.2 \%$ o- $0.6 \% \mathrm{NaCl}$. It can be concluded that the microbial strains RA18, P1107, S3.1 and PT5.1 can grow in the sandy soil of research area.

\section{Conclusions}

Sandy soil in Binhdinh province has low moisture, organic matter, $\mathrm{pH}$, total available nutrients, population of beneficial microbes and high salinity. There is the main limitation for agricultural production in this area. The rhizobial strain RA18 has an N-fixing activity value of 3,458 $\pm 10.95 \mathrm{nmol} \mathrm{C}_{2} \mathrm{H}_{2}$ /plant and can supply $30 \%$ of required $\mathrm{N}$ for peanut, while the bacterial strain P1107 is able to solubilize phosphate and can increase P uptake by $30 \%$ in peanut. Inoculation of peanut with the bacterial strain S3.1 can save 30\% required mineral $\mathrm{K}$ and the Lipomyces strain PT5.1 can produce the slime, which can provide the sandy soil to keep moisture for $15 \mathrm{~d}$ longer than the control without the inoculation. All selected isolates are able to grow at temperatures from $20^{\circ} \mathrm{C}$ to $35{ }^{\circ} \mathrm{C}, \mathrm{pH}$ from 4.5 to 6.0 , salinity of $0.2 \%$ o- $0.6 \% \mathrm{NaCl}$, and can well adapt to the sandy soil conditions.

The selected microbial strains (RA18, P1107, S3.1 and PT5.1) have positive effects on growth, yield of peanut growing in sandy soil and can be used as biofertilizer to improve the fertility of sandy soil.

\section{References}

[1] Tambekar, D. H., Gulhane, S. R., Somkuwar, D. O., Ingle, K. B., Kanchalwar, S. P., Upadhye, M. A., and Bidwai, U. A. 2009. "Potential Rhizobium and Phosphate Solubilizers as a Biofertilizers from Saline Belt of Akola and Buldhana District (India).” India Res. J. Agric. Biol. Sci. 5 (4): 578-82.

[2] Kannaiyan, S. 2002. "Biofertilizers for Sustainable Crop Production.” In Biotechnology of Biofertilizers. New Delhi, India: Narosa Publishing House, 377.

[3] Chang, C. H., and Yang, S. S. 2009. "Thermo-Tolerant Phosphate-Solubilizing Microbes for Multi-functional Biofertilizer Preparation.” Biores. Technol. 100 (4): 1648-58.

[4] Banerjee, S., Palit, R., Sengupta, C., and Standing, D. 2010. "Stress Induced Phosphate Solubilization by Arthrobacter sp. and Bacillus sp. Isolated from Tomato Rhizosphere.” Aust. J. Crop Sci. 4 (6): 378-83.

[5] Son, T. T. N., Diep, C. P., and Giang, T. T. M. 2006. "Effect of Bradyrhizobia and Phosphate Solubilizing Bacteria Application on Soybean in Rotational System in the Mekong Delta." Omonrice 14: 48-57.

[6] Akhtar, M. S., and Siddiqui, Z. A. 2009. "Effect of Phosphate Solubilizing Microorganisms and Rizobium sp. on the Growth, Nodulation, Yield and Root-Rot Disease Complex of Chickpea under Field Condition.” Afr. J. Biotech. 8 (15): 3489-96.

[7] Mohammadi, K., Ghalavand, A., Aghaalikhani, M., Heidari, G. R., and Sohrabi, Y. 2011. "Introducing a Sustainable Soil Fertility System for Chickpea (Cicer arietinum L.).” Afr. J. Biotech. 10 (32): 6011- 20.

[8] Toan, P. V. 2002. "Study on the Using New Technology to Extending the Production and Application of Nitrogen Fixing and Phosphate Solubilizing Biofertilizer for Sustainable Development of Agriculture.” Presented at Finishing Meeting of National R\&D Program at the Period of 1996-2000, December, 2002, Hanoi. (in Vietnamese)

[9] Food and Agricultural Organization of the United Nations (FAO). 2015. "Production and Trade Data for Groundnuts (Peanuts).” FAOSTAT, FAO, Statistics Division. Accessed August 2016. http://www.faostat3.fao.org.

[10] Vinh, T. C. 2006. "Coastal Sandy Soils and Constraints for Crops in Binh Thuan Province, Southern Central Vietnam." In Proceeding of the First Symposium of FAO Regional Office for Asia and the Pacific on the Management of Tropical Sandy Soils, 60-7.

[11] Ha, P. Q., Hien, B. H., Hoa, H. T. T., Tu, P. K., Ninh, H. 
T., Loan, B. T. P., Quynh, V. D., and Dufey, J. E. 2006. "Overview of Sandy Soils Management in Vietnam." In Proceeding of the First Symposium of FAO Regional Office for Asia and the Pacific on the Management of Tropical Sandy Soils, 348-53.

[12] Vietnam Standards. 2005. "Soil Quality—Guideline to Take the Samples.” TCVN 7538-2:2005. Accessed August 2016. http://www.tcvn.gov.vn/. (in Vietnamese)

[13] Vietnam Standards. 2011. "Soil Quality-Method for Determination of Total Potassium.” TCVN 8660:2011. Accessed August 2016. http://www.tcvn.gov.vn/. (in Vietnamese)

[14] Vietnam Standards. 2011. "Soil Quality-Method for Determination of Available Potassium.” TCVN 8662:2011. Accessed August 2016. http://www.tcvn.gov.vn/. (in Vietnamese)

[15] Vietnam Standards. 2011. "Soil Quality-Method for Determination of Total Phosphorus.” TCVN 8940:2011. Accessed August 2016. http://www.tcvn.gov.vn/. (in Vietnamese)

[16] Vietnam Standards. 2009. "Soil Quality-Method for Determination of Available Phosphorus.” TCVN 5256:2009. Accessed August 2016. http://www.tcvn.gov.vn/. (in Vietnamese)

[17] Vietnam Standards. 2011. "Soil Quality—Method for Determination of Total Organic Carbon by Using Walkley Black Method.” TCVN 8941:2011. Accessed August 2016. http://www.tcvn.gov.vn/. (in Vietnamese)

[18] Vietnam Standards. 1999. "Soil Quality-Method for Determination of Total Nitrogen by Using Modified Kjedahl Method.” TCVN 6498:1999. Accessed August 2016. http://www.tcvn.gov.vn/. (in Vietnamese)

[19] Berk, D. P., Materon, L. A., and Afandi, R. 1993. Practical Rhizobium-Legume Technology Manual. Aleppo, Syria: International Center for Agricultural Research in Dry Areas (ICARDA).

[20] Vietnam Standards. 2010 "Biofertilizer-Method for Determination of Nitrogen Fixing Activity of Rhizobia
Symbiosed with the Leguminose Crops.” TCVN 8564:2010. Accessed August 2016. http://www.tcvn.gov.vn/. (in Vietnamese)

[21] Sugumaran, B., and Janarthanam, B. 2007. "Solubilization of Potassium Containing Mineral by Bacteria and Their Effect on Plant Growth.” World J. Agric. Sci. 3 (3): 350-5.

[22] Gaur, A. C. 1990. Phosphate Solubilizing Microorganisms as Biofertilizer. New Dehli: Omega Scientific Publisher, 176.

[23] Tam, N. K. B. 2009. "Study on Application of Lipomyces Inoculant for Soil Moisture and Soil Fertil Parameters Improvement in Melinh, Vinhphuc.” Ph.D. thesis, Colleage of Natural Sciences, National Hanoi University. (in Vietnamese)

[24] Vietnam Standards. 2011. "Soil Quality-Method for Determination of Soil Moisture.” TCVN 4048:2011. Accessed August 2016. http://www.tcvn.gov.vn/. (in Vietnamese)

[25] Hiep, N. H. 2009. "Effect of Nitrogen Fixing and Phosphate Solubilizing Bacteria on Yield of Peanut Growing in Sandy Soil of Travinh Province.” Journal of Sciences 11: 134-45.

[26] Badr, M. A. 2006. "Efficiency of K-Feldspar Combined with Organic Material and Silicate Dissolving Bacteria on Tomato Yield.” J. App. Sci. Res. 2 (12): 1191-8.

[27] Sheng, X. F. 2005. "Gowth Promotion and Increased Potassium Uptake of Cotton and Rape by a Potassium Releasing Strain of Bacillus adaphicus." Soil Bio. Biochem. 37 (10): 1918-22.

[28] Pan, C. C., Liu, C. A., Zhao, H. L., and Wang, Y. 2013. "Changes of Soil Physico-Chemical Properties and Enzyme Activities in Relation to Grassland Salinization.” Eur. J. Soil Biol. 55: 13-9.

[29] Yuan, B. C., Li, Z. Z., Liu, H., Gao, M., and Zhang, Y. Y. 2007. "Microbial Biomass and Activity in Salt Affected Soils under Arid Conditions.” Appl. Soil Ecol. 35 (2): 319-28. 